\title{
SURFACE MORPHOLOGY OF SOME AMPHISTOMES (TREMATODA) OF AMAZONIAN FISHES AND THE DESCRIPTION OF A NEW GENUS AND SPECIES
}

\author{
Vernon E. THATCHER*
}

\begin{abstract}
The surface morphology of specimens from ten different genera of amphistomes (Trematoda, Cladorchiidae) from Amazonian fishes is described and illustrated. The importance of body shape as a generic character is considered. Morphological changes as a result of growth are shown and explained in relation to the species Dadaytrema oxycephala. Additionally, Doradamphistoma bacuensis gen. et $\mathrm{sp}$. $\mathrm{n}$. is described from the catfish, Megalodoras irwini Eigenmann, 1925. The new genus and species is elongate and flattened, with external pharyngeal pouches, an esophageal bulb, a spherical cirrus sac, a post-bifurcal genital pore and preequatorial testes.
\end{abstract}

Key-words: fish parasite, trematode, amphistome, Amazonia, Brazil.

A Morfologia Superficial de Alguns Anfistomideos (Trematoda) de Peixes Amazônicos e a Descrição de um Novo Gênero e Espécie

RESUMO - A morfologia superficial de espécimens representando dez gêneros diferentes de anfístomos (Trematoda, Cladorchiidae) de peixes amazônicos é descrita e ilustrada. A importância da forma do corpo como caracter genêrico é considerada. Modificações morfológicas, como resultado do crescimento, são mostradas e explicadas em relação à espécie Dadaytrema oxycephala. Adicionalmente, Doradamphistoma bacuensis gen. et sp. n. é descrito de um bagre amazônico, Megalodoras irwini. A espécie nova é alongada e achatada, com sacos faringiais externos, um bulbo esofageano, uma bolsa de cirro esférica, um poro genital pós-bifurcal e testículos pré-equatoriais.

Palavras-chaves: parasita de peixes, trematódeo, anfístomídeo, Amazônia, Brasil.

\section{INTRODUCTION}

Body shape in trematodes has frequently been ignored. In fact, some specialists have recommended artificially flattening specimens so that internal organs may be more easily seen. Sey (1991), in his extensive monograph on amphistomes, has pointed out that body shape can be used to characterize genera and even families if the specimens have been killed in a relaxed position. In a series of studies on amphistomes of Amazonian fishes (Thatcher, 1979; 1992a; 1992b; Thatcher \& Jégu, 1996; Thatcher et al., 1996) it has been shown that internal anatomy is often less useful than external shape for distinguishing genera. The present paper explains and illustrates some of these differences in shape. Additionally, morphological changes resulting from growth are considered in Dadaytrema oxycephala, and a new genus and species from a catfish is described.

\section{MATERIALS AND METHODS}

Fish hosts were netted, identified and eviscerated. The intestinal tracts were fixed in $10 \%$ formalin solution

\footnotetext{
*Instituto Nacional de Pesquisas da Amazônia, Manaus, AM, Brazil. Research Fellow of the Conselho Nacional de Pesquisas (CNPq), Brasilia, Brazil.
} 
and later transferred to $70 \%$ alcohol. The fixed digestive tracts were opened and washed in tap water. Trematodes were recovered in finger bowls by hand sedimentation. Permanent slides were made by the phenol-balsam method described in Thatcher (1993). Drawings were made with the aid of a camera lucida and sizes were taken with a measuring ocular. Measurements are in micrometers $(\mu \mathrm{m})$ unless indicated as millimeters $(\mathrm{mm})$ and the means are followed by the extremes.

\section{RESULTS}

\section{Cladorchiidae Southwell \& Kirshner, 1937}

\section{Dadaytrematinae Yamaguti, 1958}

\section{Doradamphistoma gen. $\mathrm{n}$.}

Generic diagnosis: With the characters of the family. Body elongate, flattened, sides nearly parallel, extremities bluntly rounded. Pharynx large, with prominent external diverticula; esophagus long, bulb present; ceca reaching to near acetabulum. Acetabulum small, subterminal. Testes diagonal, equatorial or pre-equatorial; cirrus sac small, subspherical; genital pore postbifurcal. Ovary ovoid, postequatorial; vitellaria consisting of few large follicles lateral to ovary and extracecal; uterus extensive, with descending and ascending loops; eggs numerous; ovoviviparous. Excretory vesicle saccular; pore dorsal. Intestinal parasites of Amazonian catfishes.

Type species: Doradamphistoma bacuensis $\mathrm{sp} . \mathrm{n}$.

Doradamphistoma bacuensis sp. $\mathbf{n}$.

\section{(Figs. 1 \& 8)}

Host: Megalodoras irwini Eigenmann, 1925; Doradidae.

Site: Intestinal lumen.

Locality: Manaus, Amazonas, Brazil. (Colector: J.C. Malta. 11/28/1984)

Holotype (INPA 371) and 5 paratypes (INPA 372 a-e): Invertebrate Collection of the Instituto Nacional de Pesquisas da Amazônia - Platyhelminthes. Manaus, Amazonas, Brazil.

Etymology: The generic name incorporates the family name of the host fish and the specific name comes from the common name (bacu) of the host.

Species diagnosis (6 specimens measured): With the characters of the genus. Body 7.6 (6.0-9.6) $\mathrm{mm}$ long and $2.4(1.8-3.1) \mathrm{mm}$ wide. Pharynx $1,081(832-1,330)$ long and 763 (624$832)$ wide; esophagus $1,402(1,248$ $1,560)$ long and 255 (130-416) wide; esophageal bulb 349 (261-470) long by 302 (261-348) wide. Anterior testis 513 (435-609) long by 563 (609$783)$ wide; posterior testis 472 (416$522)$ long by $801(522-1,305)$ wide; cirrus sac 244 (200-261) long and 244 $(200-261)$ in diameter. Ovary 435 (348-522) long and 653 (539-811) wide; vitelline follicles $88-174$; proximal eggs $96 \times 53$ (88-104 x 52-55); distal eggs containing miracidia $167 \mathrm{x}$ $100(132-191 \times 88-110)$.

\section{Remarks}

Doradamphistoma bacuensis gen. et sp. n. somewhat resembles Pacudistoma turgida Thatcher, 1992, in size and organ distribution. However, the new form is much more flattened, 


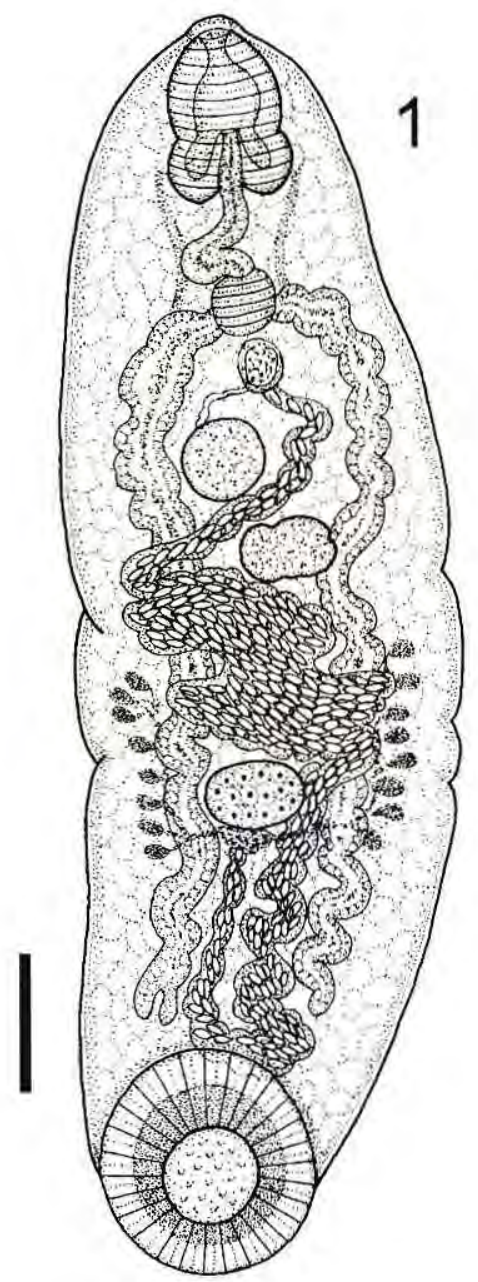

Figure 1. Doradamphistoma bacuensis gen. et sp. $\mathrm{n}$. (ventral aspect). Scale $=1 \mathrm{~mm}$

lacks a genital sucker, has a postbifurcal genital pore, a subspherical cirrus sac and an esophageal bulb.

\section{Morphological Variation with Growth}

Dadaytrema oxycephala (Diesing,
1836) Travassos, 1931, was redescribed from Amazonian material by Thatcher (1979). Figures 2-6 show some of the morphological changes that result from growth in this species. D. oxycephala has been reported from several different host species and is widely distributed in Brazil. In Amazonia, it is a common parasite of the "pirapitinga", Piaractus brachypomus (Cuvier), and of certain catfishes, especially Pterodoras granulosus (Valenciennes).

Young specimens measuring slightly more than one millimeter in length (Fig. 2) show little or no development of internal organs. The body is cylindrical like that of adults but the pharynx and acetabulum are relatively larger. Specimens around two millimeters in length (Fig. 3 ) have the testes and ovary developed but the cirrus sac and uterus are rudimentary. In such young trematodes the testes are nearly equatorial. After reaching about three millimeters in length (Figs. 5, 6), the worms have well developed cirrus sacs and a few eggs appear in the uterus. In worms of this size, the testes are still equatorial. Fully mature worms measuring more than four millimeters (Fig. 4) have numerous uterine eggs and the testes are pre-equatorial. In these adult worms, the pharynx and acetabulum are relatively smaller.

\section{Variations in External Shape}

Figures 7-16 demonstrate some of the body shapes found in fish parasitic amphistomes in Amazonia. Some of these forms are unique and have not been reported from other hosts in other 

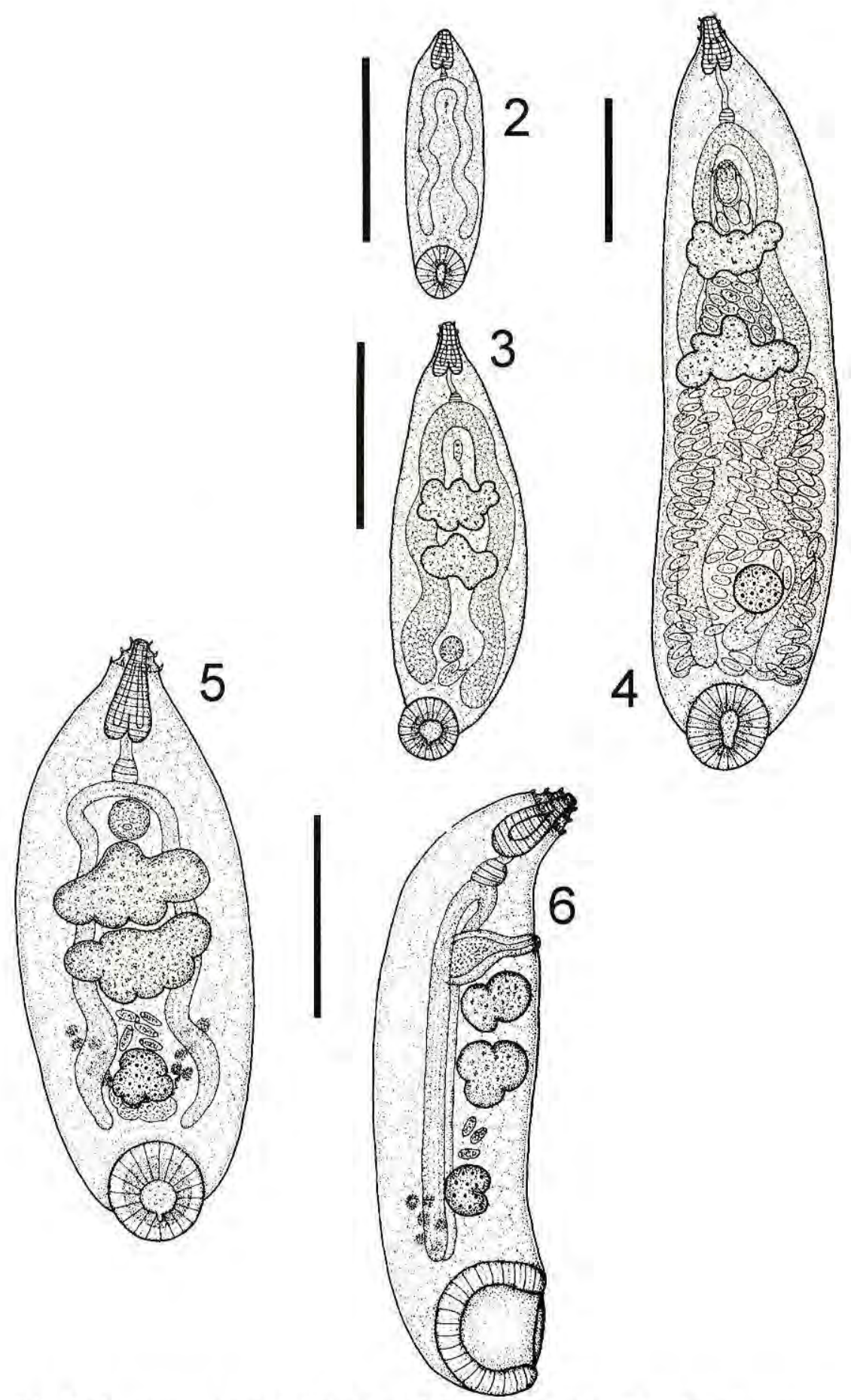

Figures 2-6. Dadaytrema oxycephala (Diesing, 1836). Growth series. All scales $=1 \mathrm{~mm}$. 
areas of the world.

Figure 7 represents Micramphistoma ministoma Thatcher, 1992, from the intestinal tract of Hypopomus sp., a gymnotiform fish caught in the Guapore River of Rondônia State, Brazil. In addition to having a flattened body, the acetabulum is extremely small. Internally, the phar$\mathrm{ynx}$ is also small and lacks diverticula.

Figure 8 is an external view of Doradamphistoma bacuensis gen. et sp. $\mathrm{n}$., which is described herein. This species has an elongate and flattened body in contrast to the cylindrical body of Pacudistoma turgida Thatcher, 1992, (Fig. 9) described from the "pacu", Myleus pacu Cuvier, from the Jamari River of Rondônia State, Brazil.

Figure 10 is an external view of Zetamphistoma compacta Thatcher \& Jégu, 1996, from Mylesinus paraschomburgkii Jégu, Santos \& Ferreira, taken in the Araguari River, Amapá State, Brazil. This species has a broad, flattened body which is thicker centrally and thins towards the perifery. The acetabulum is relatively large and the circlets of papillae around the mouth are pronounced.

Figure 11 is an externo-ventral view of Dadayius pacuensis Thatcher, Sey \& Jégu, 1996, described from Myleus (Myloplus) asterias Cuvier from both Amazonas and Rondônia States. This species has a pyramidal or conical body with a massive acetabulum and a genital sucker. There are horizontal corrugations in the inner wall of the acetabulum.

Figures $12 \& 13$ show two genera that are nearly cylindrical and each has a collar-like anterior expansion, although they are probably not closely related. Figure 12 is an external view of Pronamphistoma cichlasomae Thatcher, 1992, which was described from Cichlasoma severum (Steindachner) taken in the Guapore River of Rondônia. This is a very small species measuring only about one millimeter long and it has a relatively large acetabulum. Figure 13 is a view of Anavilhanatrema robusta Thatcher, 1992, from the "piranha", Pristobrycon striolatus Kner, from the Negro River of Amazonas State. This species is much larger and can reach more than 12 millimeters in length.

Figure 14 shows an externo-ventral view of Dadaytrema oxycephala (Diesing, 1836) from the catfish, Pterodoras granulosus, taken in the Amazon River near Manaus. This species is cylindrical with a tapered anterior extremity bearing four or five circles of papillae. The acetabulum has a prominent posterior notch in the opening.

Figure 15 is an externo-ventral view of Alphamphistoma canoeforma Thatcher \& Jegu, 1996, from Mylesinus paraschomburgkii. This species is as widely distributed as its host in the Northern tributaries of the Amazon River. It is extremely concave ventrally and the sides of the body fold in to give it a canoe-like appearance. These worms probably use the entire ventral surface as a sucker to adhere to the intestinal wall of the fish host.

Figure 16 is a externo-dorsal view of Annelamphistoma elegans Thatcher, Sey \& Jégu, 1996, taken from Myleus 



Figures 7-11. Surface morphology of some amphistomes from Amazonian fishes. Ventral views; all scales $=1 \mathrm{~mm}$, except for figures $7 \& 11=0.5 \mathrm{~mm}$.

7. Micramphistoma ministoma Thatcher, 1992.

8. Doradamphistoma bacuensis gen. et sp. $\mathrm{n}$.

9. Pacudistoma turgida Thatcher, 1992.

10. Zetamphistoma compacta Thatcher \& Jégu, 1996.

11. Dadayius pacuensis Thatcher, Sey \& Jégu, 1996. 

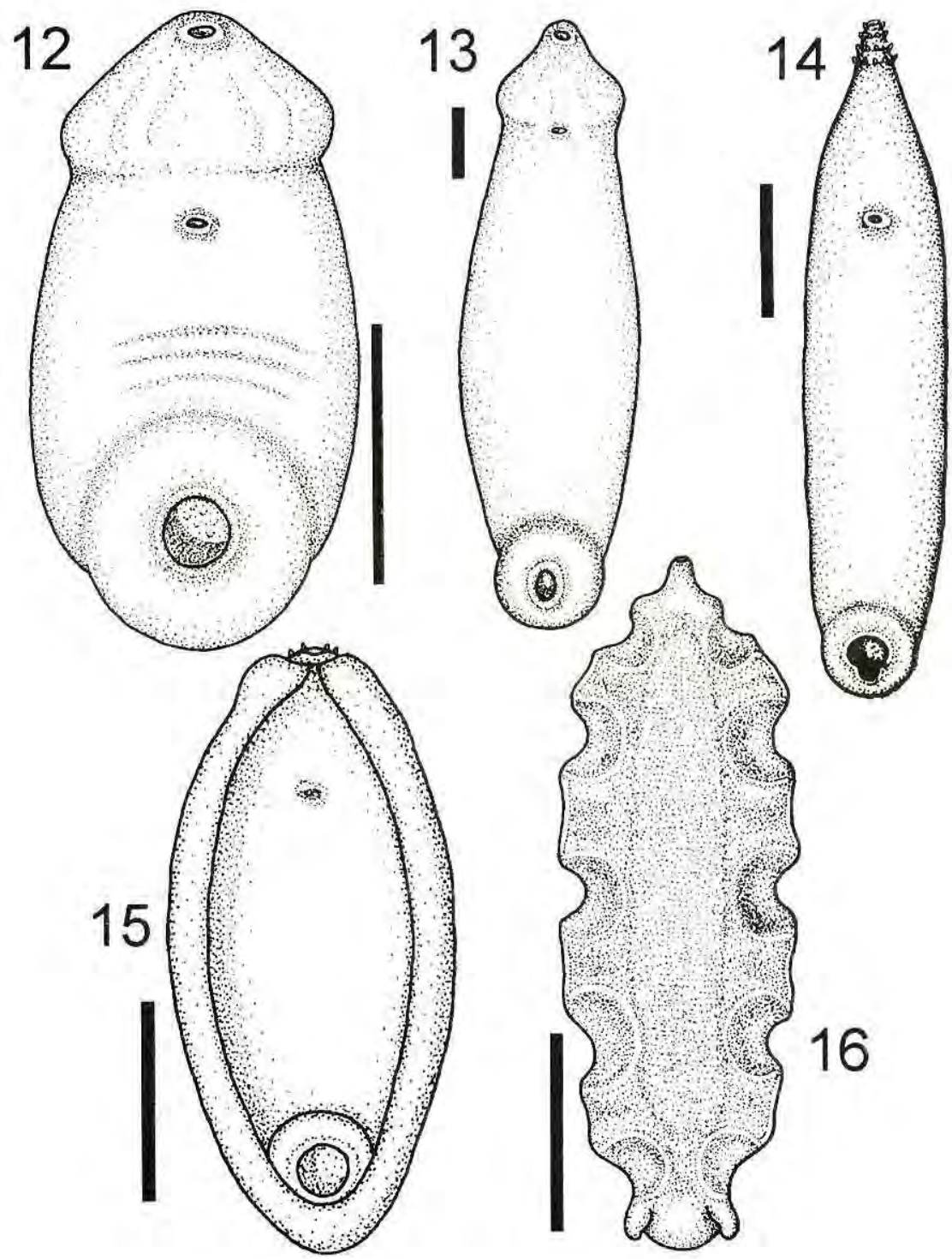

Figures 12-16. Surface morphology of some amphistomes from Amazonian fishes.

Figs. 12-15. ventral views; 16. dorsal view; all scales $=1 \mathrm{~mm}$, except for figure $13=0.5 \mathrm{~mm}$.

12. Pronamphistoma cichlasomae Thatcher, 1992.

13. Anavilhanatrema robusta Thatcher, 1992.

14. Dadaytrema oxycephala (Diesing, 1836).

15. Alphamphistoma canoeforma Thatcher \& Jégu, 1996.

16. Annelamphistoma elegans Thatcher, Sey \& Jégu, 1996. 
(Myloplus) spp. Apparently, the species is widely spread in Amazonia. It has a very unusual shape in that it is convex ventrally and concave dorsally. Also, these worms have five muscular or tegumental puckers on either side and the ventral surface is entirely covered with small papillae.

It can be concluded that there are amphistomes of many shapes and sizes infecting Amazonian fishes. These different body shapes should be taken into consideration when describing genera. Body form constitutes an important character which can be used at the generic and possibly the family levels.

\section{Literature Cited}

Sey, O. 1991. Handbook of the Zoology of Amphistomes. C.R.C. Press, Boca Raton, Florida. $480 \mathrm{pp}$.

Thatcher, V.E. 1979. Paramphistomidae (Trematoda: Digenea) de peixes de água doce: dois novos gêneros de Colômbia e uma redescrição de Dadaytrema oxycephala (Diesing, 1836) Travassos, 1934, da Amazônia. Acta Amazonica, 9: 203-208.

Thatcher, V.E. 1992a. Two new genera of Paramphistomidae (Trematoda, Digenea) from freshwater fish of Rondônia State Brazil. Mem. Inst. Oswaldo Cruz (Suplemento em homenagem ao centenário de nascimento do Prof. Lauro Travassos), 87(Supl. 1): 287-291.

Thatcher, V.E. 1992b. Two unusual new genera of Paramphistomidae (Trematoda, Digenea) from freshwater fish of the Brazilian Amazon. Acta Amazonica, 22: 609-613.

Thatcher, V.E. 1993. Trematódeos Neotropicais. INPA, Manaus, Brazil. 553 pp.
Thatcher, V.E.; Jégu, M. 1996. Intestinal helminths as population markers of the Amazonian fish, Mylesinus paraschomburgkii. with descriptions of five new genera and seven new species of trematodes. Amazoniana, 14: 143-155.

Thatcher, V.E.; Sey, O.; Jégu, M. 1996. New amphistome (Trematoda) genera and species from Amazonian serrasalmid fishes, Myleus (Myloplus), Acta Zool. Acad. Scient. Hungaricae. 42: 261-270. 